\title{
Matrigel influences morphology and cathepsin B distribution of prostate cancer PC3 cells
}

\author{
PURVA GOPAL, REIAZ U. REHMAN, KANWARJEET S. CHADHA, MENGSHING QIU and RITA COLELLA
}

\author{
Department of Anatomical Sciences \& Neurobiology, \\ University of Louisville School of Medicine, Louisville, KY 40292, USA
}

Received February 24, 2006; Accepted March 27, 2006

\begin{abstract}
Increases in expression and activity of matrixdegrading enzymes such as the cysteine proteinases cathepsins $\mathrm{B}$ and L, and abnormal levels of their inhibitors, the cystatins, are associated with tumor cell invasion and metastasis. Environmental conditions have been shown to be causative factors in the development of a metastatic/invasive phenotype. We hypothesized that cell-matrix interactions affect the expression and activity of cathepsins B and L and their inhibitors in the prostate cancer cell lines, PC3 and DU145. To test this possibility, PC3 and DU145 were plated on uncoated surfaces or on surfaces coated with the reconstituted basement membrane, Matrigel. The cells were analyzed for cathepsins B and $\mathrm{L}$ immunolocalization, protein expression and activity $48 \mathrm{~h}$ after plating. Our data demonstrated that cathepsins B and L displayed a distinct punctate distribution with little colocalization; individual cells displayed a predominant staining for one or the other enzyme. Cathepsin B had a perinuclear distribution in PC3 grown on uncoated surfaces but a more peripheral staining in PC3 plated on Matrigel. Localization of cathepsin L remained predominantly perinuclear regardless of the plating surface. In addition to the translocation of cathepsin B from a perinuclear distribution to the cell periphery, growth of PC3 on Matrigel shifted cathepsin B activity from the cell extract to the media. There were no significant changes in cathepsins B and L immunolocalization or activity in DU145 with regard to plating surfaces. Likewise, the activity of endogenous cysteine proteinase inhibitors (CPIs) and protein expression of cystatin $\mathrm{C}$ remained unchanged in both cell lines. In conclusion, the interaction of PC3 prostate cancer cells with extracellular matrix components affects the distribution of cathepsin B protein and activity.
\end{abstract}

Correspondence to: Dr Rita Colella, Department of Anatomical Sciences \& Neurobiology, 500 South Preston Street, Louisville, KY 40292, USA

E-mail: r0cole01@gwise.louisville.edu

Key words: cathepsin B, cathepsin L, cysteine proteinase inhibitor, immunolocalization, Matrigel, prostate cancer cell lines

\section{Introduction}

A primary cause of death from cancer is invasion and metastasis of cells from the primary tumor to distant sites. The ability of a cancer cell to detach from adjacent cells and its supporting extracellular matrix is partly dependent on the activities of a number of proteinases including matrix metalloproteinases, plasminogen activators, and the cathepsins (1-4). These proteinases facilitate the breakdown of cell adhesion molecules, basement membranes, vascular channels, and possibly other cell regulatory molecules; their activity may also be responsible for the release of regulatory factors from the surrounding matrix. It is no surprise that the activities and expressions of many proteinases are increased in a number of cancers and cancer cell lines. This study focuses on the cysteine proteinases, cathepsins B and L. Cathepsins B and L are lysosomal proteinases; they acquire mannose-6-phosphate (M6P) residues during their synthesis that target them to lysosomal vesicles via the M6P receptor. In many cancer cells, however, cathepsins $\mathrm{B}$ and $\mathrm{L}$ are either secreted or associate with the plasma membrane and with caveolae (5-8). Both proteinases can degrade components of the extracellular matrix in vitro (9-14) and can activate other matrix-degrading enzymes $(15,16)$ suggesting that they contribute in a significant way to the metastatic ability of cancer cells. Lysosomal degradation of matrix components by the cathepsins has also been demonstrated in cancer cells $(17,18)$.

The extracellular matrix is an important regulator of cellular differentiation and behavior; it also plays an active role in the development of the metastatic phenotype. A hallmark of metastasizing cells is their increased ability to migrate and invade adjacent tissue in most cases by altered expression of cellcell and cell-matrix adhesion molecules. Adhesion molecules, in turn, participate in cell signaling cascades that relay information from the environment to the cell nucleus with resulting changes in gene expression patterns and cell behavior (19-21). Migration and invasion also involve cytoskeletal rearrangements necessary for cell locomotion; cytoskeletal components are responsible for the arrangement and location of cell organelles including lysosomes. We propose that the changes in cathepsin expression, activity and location result from the interaction of cancer cells with tumor-altered components of the extracellular matrix. Matrigel is a reconstituted basement membrane composed predominantly of laminin but also contains collagen IV, heparin sulfate proteoglycans, 
entactin, and nidogen (BD Biosciences, SPC354234). Matrigel is used in many studies of cell-matrix interactions including prostate cell lines (22). Matrigel enhanced the growth of human prostatic carcinoma cell lines injected into nude mice (23) and increased their invasive and tumorigenic properties (24). Since cathepsins B and L are implicated in prostate tumor growth and invasion $(3,4,25-29)$ we analyzed the effect of cell-Matrigel interactions on the expression and activity of cathepsins B and L in the prostate cancer cell lines, PC3 and DU145. This study demonstrates that the location of active cathepsin B is modulated by the interaction of PC3 cells with Matrigel.

\section{Materials and methods}

Materials. The prostate cancer cell lines, DU145 and PC3, were obtained from the American Type Culture Collection (ATCC, Rockville, MD). Matrigel was obtained from BectonDickinson (Bedford, MA). All other culture reagents were obtained from Gibco/Invitrogen (Grand Island, NY). The cathepsin substrates, Z-phe-arg-aminomethylcoumarin (Zphe-arg-NMec), Z-arg-arg-aminomethylcoumarin (Z-arg-arg$\mathrm{AMC}$ ), and the standard 7-amino-4-methylcoumarin (AMC) were purchased from Bachem (Torrance, CA). CentriconYM10 columns were from Millipore (Bedford, MA). Reagent sources for the immunolocalization studies were as follows: 4',6-diamidino-2-phenylindole (DAPI) for DNA staining (Molecular Probes, Eugene, OR), polyclonal antibody to cathepsin L (Calbiochem, San Diego, CA), and polyclonal antibody to cathepsin B (R\&D Systems, Minneapolis, MN). Secondary antibodies were donkey anti-rabbit conjugated to Rhodamine $\mathrm{Red}^{\mathrm{TM}}-\mathrm{X}$ for cathepsin $\mathrm{L}$ and donkey anti-goat conjugated to $\mathrm{Cy}^{\mathrm{TM}} 2$ for cathepsin $\mathrm{B}$ (Jackson ImmunoResearch, West Grove, PA). Antibodies used for Western blotting included polyclonal anti-cathepsin L (Calbiochem), polyclonal anti-cathepsin $\mathrm{B}$, and polyclonal anti-cystatin $\mathrm{C}$ (Novus, Littleton, CO). Precast acrylamide gels were obtained from Invitrogen (Carlsbad, CA). The ECL kit was from Amersham (Piscataway, NJ). Protran ${ }^{\circledR}$ nitrocellulose transfer membrane was obtained from Schleicher \& Schuell (Keene, $\mathrm{NH})$. All other reagents were from Sigma (St. Louis, MO) or Fisher (Cincinnati, OH).

Cell culture. The human prostate carcinoma cell lines DU145, established from a metastatic lesion in the central nervous system of a 69-year-old man (30) and PC3, established from a lumbar vertebra metastasis of a 62-year-old man (31) were maintained according to ATCC specifications. The reconstituted basement membrane Matrigel (undiluted or diluted $1: 3$ with F-12K media) was spread on 60 -mm plastic dishes (for enzyme analysis) or 22-mm round coverslips (for immunocytochemistry) and allowed to dry at room temperature for $1 \mathrm{~h}$. Pre-coated 60-mm Matrigel dishes were also used for enzyme assays. The concentration of Matrigel per $\mathrm{cm}^{2}$ of surface was calculated as $\sim 70-80 \mu \mathrm{g} / \mathrm{cm}^{2}$ for a thin layer of Matrigel or pre-coated dishes and $0.5-0.6 \mathrm{mg} / \mathrm{cm}^{2}$ for a thin gel of Matrigel. PC3 and DU145 were plated at a concentration of $5.0 \times 10^{5}$ cells per $60 \mathrm{~mm}$ dish and at $2 \times 10^{4}$ cells per $22-\mathrm{mm}$ coverslip. The cells were maintained in culture for a total of $48 \mathrm{~h}$ and fed with serum-free media $12-18 \mathrm{~h}$ prior to collection and analysis.
Immunocytochemistry. Cells were plated on a thin layer of Matrigel on 22-mm glass coverslips for immunolocalization of cathepsins B and L. Prior to fixation, cells were reacted with DAPI for $30 \mathrm{~min}$ at $37^{\circ} \mathrm{C}$ for DNA staining. Cells were fixed in $3 \%$ paraformaldehyde and permeabilized with cold acetone. Non-specific binding sites were blocked with a 1:20 dilution of normal donkey serum in phosphate-buffered saline (PBS). Primary antibodies (polyclonal antibody to cathepsin L and polyclonal antibody to cathepsin B) were diluted 1:200 with PBS $+0.05 \%$ Tween, added sequentially to slides and allowed to react for $1 \mathrm{~h}$ and overnight, respectively. Secondary antibodies, diluted 1:50 with PBS $+0.05 \%$ Tween, were donkey anti-rabbit conjugated to Rhodamine Red-X for cathepsin L and donkey anti-goat conjugated to $\mathrm{Cy} 2$ for cathepsin B; slides were incubated with secondary antibodies for $1 \mathrm{~h}$ at room temperature following reaction with the primary antibody and extensive washing with PBS-Tween. Coverslips were mounted on glass slides with Mowiol (Calbiochem, La Jolla, CA) and examined with an Olympus confocal microscope.

Western blot analysis. Cells were collected by scraping in PBS and centrifuged at 5,000 g for $5 \mathrm{~min}$. The cell pellet was resuspended in lysis buffer ( $1 \%$ nonidet P-40, $0.5 \%$ deoxycholate, $1 \%$ SDS, $1 \mathrm{mM}$ sodium orthovanadate, $0.5 \mathrm{mM}$ PMSF, $10 \mu \mathrm{g} / \mathrm{ml}$ aprotinin, $20 \mu \mathrm{g} / \mathrm{ml}$ leupeptin), lysed by sonication and placed on ice for $10 \mathrm{~min}$. The homogenate was centrifuged at $13,100 \mathrm{rpm}$ for $10 \mathrm{~min}$ at $4^{\circ} \mathrm{C}$ and the supernatant saved. Protein $(50 \mu \mathrm{g})$ from each sample was mixed $(1: 2, \mathrm{v} / \mathrm{v})$ with sample buffer $(125 \mathrm{mM}$ Tris-Cl, $\mathrm{pH} 6.5,20 \%$ (v/v) glycerol, $4 \%$ SDS, $0.025 \%$ bromophenol blue, $0.1 \mathrm{M}$ DTT ) and boiled for $5 \mathrm{~min}$. Samples were loaded on $12 \%$ (for cathepsins B and L) or 16\% (for cystatin C) precast SDSPAGE gels and run at constant voltage in a Tris-glycine running buffer (25 mM Trizma base, $0.192 \mathrm{M}$ glycine, 0.1\% SDS).

Preparation of samples for Western blot analysis of cathepsins B and $\mathrm{L}$ and cystatin $\mathrm{C}$ in the media was as follows: $10 \mu \mathrm{l}$ of the appropriate antibody was added to media (amount equivalent to $100 \mu \mathrm{g}$ protein in media and previously concentrated 100 -fold with a Centricon-YM10 column) and incubated overnight at $4^{\circ} \mathrm{C}$ with gentle rocking. The immunocomplex was captured with $20 \mu \mathrm{l}$ of protein $\mathrm{G}$ agarose beads with gentle rocking at $4^{\circ} \mathrm{C}$ for $2 \mathrm{~h}$. The agarose beads were collected by centrifugation ( $2 \mathrm{~min}$ at $14,000 \mathrm{~g}$ ) and washed 3 times with lysis buffer. The beads were resuspended in $30 \mu 1$ of sample buffer, boiled for $5 \mathrm{~min}$, centrifuged and $40 \mu 1$ supernatant loaded on SDS-PAGE gels as described above.

Following electrophoresis, proteins were transferred to Protran nitrocellulose membranes using the Invitrogen Transblot apparatus according to the manufacturer's specifications. The membrane was immersed in blocking buffer (5\% NFDM in TBS-Tween) for $1 \mathrm{~h}$ at room temperature followed by incubation in primary antibody (diluted 1:1000 for cathepsins $\mathrm{B}$ and $\mathrm{L}$, and cystatin $\mathrm{C}$ ) in blocking buffer overnight at $4^{\circ} \mathrm{C}$. After extensive washing with $0.05 \%$ Tween-20 in TBS the membranes were incubated in secondary antibody (diluted 1:2000) for $1 \mathrm{~h}$ at room temperature. Cathepsins B and L and cystatin $\mathrm{C}$ protein bands were detected by chemiluminescence 

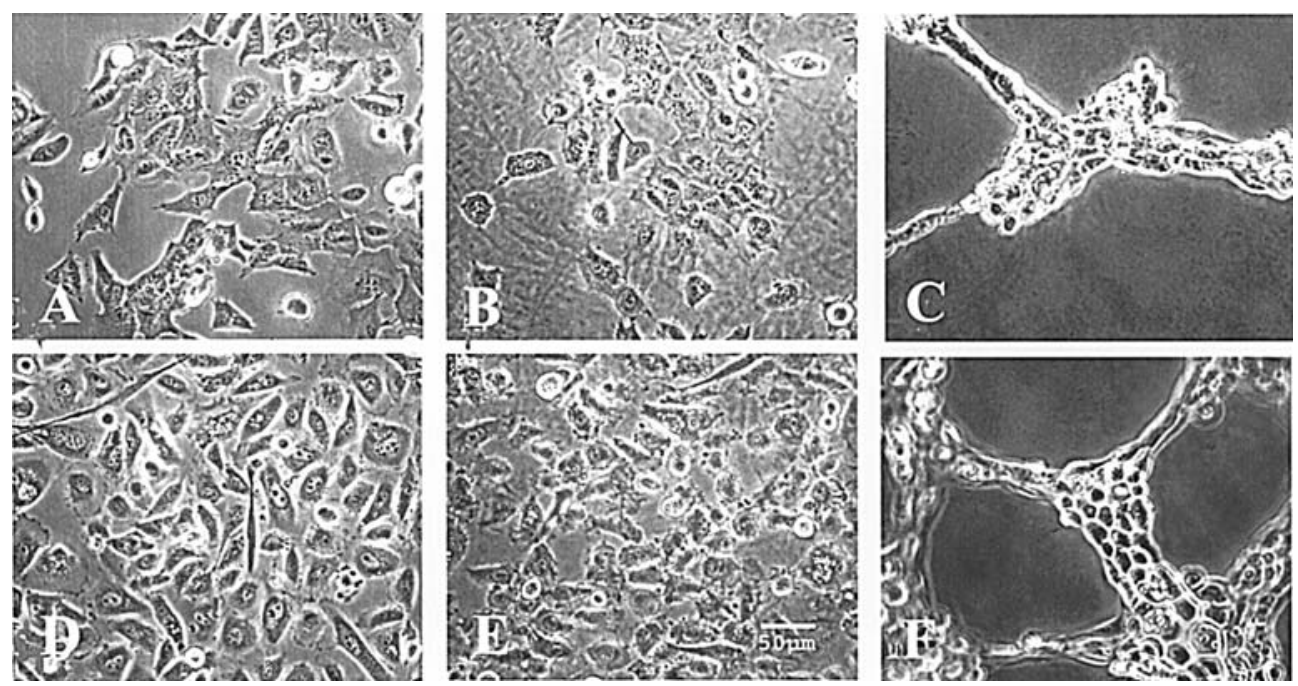

Figure 1. Phase contrast morphology of DU145 (A-C) and PC3 (D-F) grown on uncoated surfaces (A and D), or surfaces coated with either 70-80 $\mu$ g Matrigel per $\mathrm{cm}^{2}$ (B and E), or 0.5-0.6 mg Matrigel per $\mathrm{cm}^{2}$ (C and F). Surfaces coated with 70-80 $\mu \mathrm{g}$ Matrigel per $\mathrm{cm}^{2}$ form a thin protein layer for cell attachment in contrast to a gel as in surfaces coated with $0.5-0.6 \mathrm{mg}$ Matrigel per $\mathrm{cm}^{2}$. There are no apparent differences in morphology between cells growing on uncoated surfaces (A and D) or surfaces coated with a thin layer of Matrigel (B and E). Cells attached to a Matrigel gel clump together and form linear arrays (C and F). Size bar indicated in Fig. 1E.

using the ECL kit and procedure specified by Amersham Corp. (Piscataway, NJ).

Assays. Cells were fed with serum-free media $12-18 \mathrm{~h}$ prior to harvesting for enzyme and inhibitor analysis. On the day of harvesting, the serum-free medium was collected for proteinase and inhibitor assays. The cells were washed with PBS, $\mathrm{pH} 7.2$, collected in PBS, centrifuged at 3,000 $\mathrm{g}$ for $5 \mathrm{~min}$, and the pellet resuspended in PBS. The cells were lysed using a Tissue Tearor (Biospec Products Inc., Bartlesville, OK) at high speed for $5 \mathrm{sec}$, and immediately placed on ice. The cell pellet and homogenate were check microscopically at each step to ensure that the cells were completely lysed. The homogenate was centrifuged at $15,000 \mathrm{~g}$ for $15 \mathrm{~min}$ to remove cell residue, and the supernatant saved.

Cysteine cathepsin assays were done according to the procedure of Barrett and Kirschke (32) as described by Colella et al (25). Briefly, cathepsin L activity of the cell supernatant was measured using $12.5 \mu \mathrm{M}$ Z-phe-arg-NMec as substrate in $250 \mathrm{mM}$ acetate buffer, $\mathrm{pH} 5.4$, containing $2.5 \mathrm{mM}$ EDTA, and $1 \mu \mathrm{M}$ dithiothreitol (DTT). The Z-phe-arg-NMec substrate is hydrolyzed by cathepsin $\mathrm{L}$ and to a small extent by cathepsin $\mathrm{B}$; therefore, the activity is referred to as cathepsin $\mathrm{L}+\mathrm{B}$ activity (32). Cathepsin B was measured with $12.5 \mu \mathrm{M}$ Z-argarg-NMec in $250 \mathrm{mM}$ phosphate buffer, $\mathrm{pH}$ 6.0, containing $2.5 \mathrm{mM}$ EDTA and $1 \mu \mathrm{M}$ DTT. The reactions were stopped by the addition of $100 \mathrm{mM}$ monochloroacetic acid in $100 \mathrm{mM}$ acetate buffer, $\mathrm{pH}$ 4.3. Fluorescence was measured in a Perker-Elmer spectrofluorometer at an excitation wavelength of $370 \mathrm{~nm}$ and an emission wavelength of $460 \mathrm{~nm}$. Activity is expressed as $\mu \mathrm{Unit} / \mu \mathrm{g}$ protein where 1 Unit is defined as $1 \mu \mathrm{mol}$ substrate released per minute. Protein concentration was determined by the Lowry method using bovine serum albumin as standard (33).

The activities of secreted cathepsins B and L were determined as follows: Cell-conditioned media was concentrated with a Centricon-YM10 column. Cathepsin assays as described above for the cell extract were performed on concentrated media prior to and after incubation with $3 \mathrm{M}$ formate buffer, $\mathrm{pH} 3.0$ for $10 \mathrm{~min}$ at $37^{\circ} \mathrm{C}$. Acid treatment ensures that cathepsin L-cystatin complexes are broken down allowing for more accurate measurement of cathepsin $\mathrm{L}$ in crude samples (34); incubation with formate buffer under acidic conditions also cleaves procathepsins $\mathrm{B}$ and $\mathrm{L}$ into their active forms $(35,36)$.

Since there are no direct assays for measuring cystatin activity, total cysteine proteinase inhibitor (CPI) activity was indirectly measured in cell extract and conditioned media as described (25). Briefly, samples (cell extracts and conditioned media) were boiled for $5 \mathrm{~min}$, centrifuged for $10 \mathrm{~min}$ at $15,000 \mathrm{~g}$ and the supernatant incubated with the cysteine proteinase, papain using Z-phe-arg-NMec as substrate as described above for cathepsin $\mathrm{L}+\mathrm{B}$. Inhibitory activity is expressed as $\mu \mathrm{U}$ inhibitory activity per $\mu \mathrm{g}$ protein where $1 \mu \mathrm{U}$ of inhibitory activity represents the amount of papain activity inhibited per minute.

Statistics were calculated using the Student's t-test where $\mathrm{P} \leq 0.05$ was considered significant. All values are the mean \pm standard error of at least three separate experiments.

\section{Results}

Morphology of cells plated on Matrigel. The interactions between epithelial cells and components of their supporting matrix orchestrate the development of specific cell phenotypes and subsequently tissue and organ characteristics. Both cellular and stromal characteristics are altered during progression of cancer to the metastatic state; this includes the release of proteolytic enzymes that can also modify the external milieu (37). To determine if attachment to Matrigel affected cathepsins B and L expression in prostate cancer cell lines, PC3 and DU145 were initially plated on uncoated surfaces or surfaces coated with a thin gel of Matrigel (0.5-0.6 mg per $\mathrm{cm}^{2}$ ). The Matrigel thin gel induced changes in cell shape and organization such that cells formed aggregates connected to other aggregates by linear arrays of elongated cells (Fig. 1C 

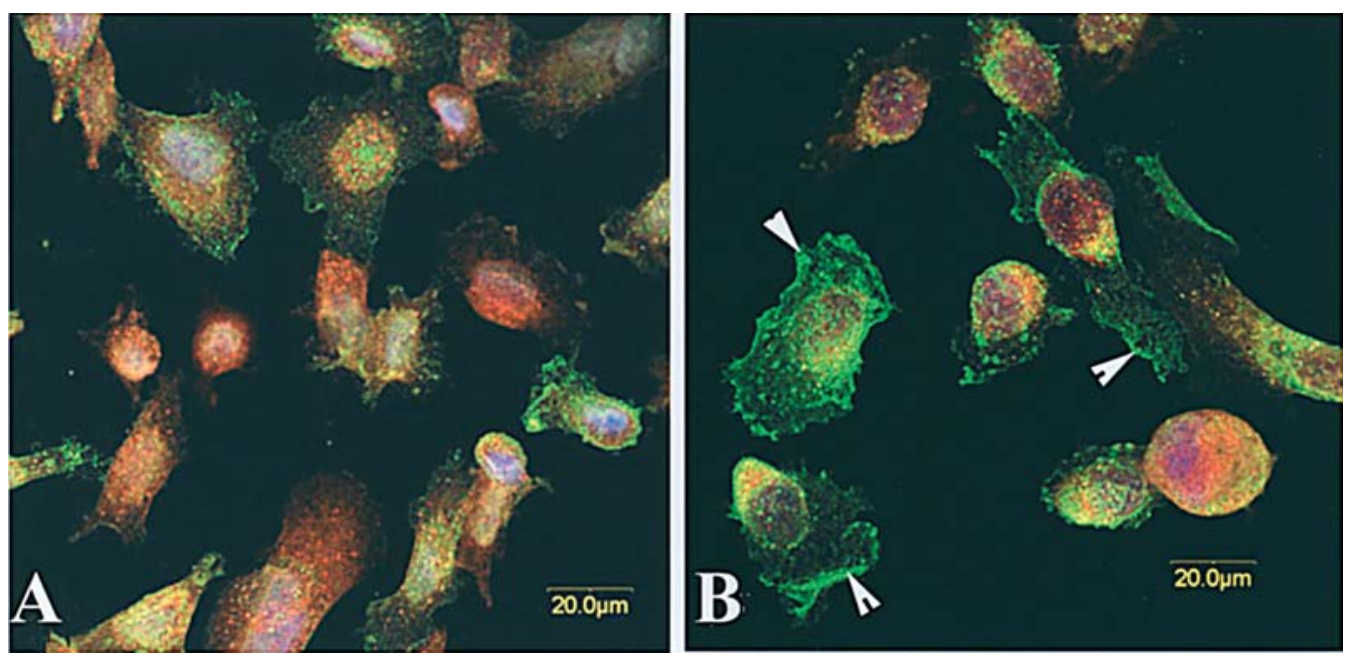

Figure 2. Immunolocalization of cathepsins B (green) and L (red) in PC3 cells plated on uncoated surfaces (A) or surfaces coated with 70-80 $\mu$ g Matrigel per $\mathrm{cm}^{2}$ (B). The cells were plated at $2 \times 10^{4}$ cells per $22-\mathrm{mm}$ round coverslip and incubated at $37^{\circ} \mathrm{C}$ for $48 \mathrm{~h}$. Prior to fixation the nuclei were stained with DAPI (blue). Co-immunolocalization of cathepsins L and B was performed as described in Materials and methods. Cathepsins L and B appear as punctate material with individual cells showing a predominant staining for either cathepsin B (green) or L (red); there is little co-localization of cathepsins B and L (as indicated by yellow-orange staining). PC3 cells on Matrigel demonstrate more cathepsin B staining toward the cell periphery (arrowhead, B) when compared to cells plated on uncoated surfaces. The distribution of cathepsin L is similar in cells plated on coated or uncoated surfaces. DU145 cells demonstrated similar distribution of cathepsins B and L as PC3 plated on uncoated surfaces; however, B and L localization did not change when DU145 was plated on Matrigel (data not shown).

and F). The aggregates were seen as early as 4-5 h following plating. The goal of this study was to determine the effects of extracellular matrix components on cathepsins L and B distribution and activity. Therefore, to eliminate the possibility that changes in cell shape also affect cathepsins L and B expression, cells were plated on a thin layer of Matrigel (70$80 \mu \mathrm{g}$ Matrigel per $\mathrm{cm}^{2}$ ). The difference between a thin layer of Matrigel versus a thin gel is that the thin layer provides a complex protein layer for cell attachment without forming a 'basement membrane' type gel as the thin gel provides (Tech sheet, BD Bioscience SPC354234). There was no difference in the morphology of PC3 and DU145 plated on uncoated surfaces (Fig. 1A and D) compared to cells plated on a thin layer of Matrigel (Fig. 1B and E). We continued our studies using a thin layer of Matrigel to maintain consistency in cell shape between cells on uncoated and coated surfaces.

Immunolocalization of cathepsins B and L. Co-immunolocalization of cathepsins $B$ and $L$ was performed on prostate cancer cell lines plated on glass coverslips or coverslips coated with 70-80 $\mu \mathrm{g}$ Matrigel per $\mathrm{cm}^{2}$. Cathepsins L and B appear as punctate material typical of a lysosomal/endosomal distribution in PC3 cells (Fig. 2). Individual cells show a predominant staining for either cathepsin $\mathrm{B}$ (green) or $\mathrm{L}$ (red). There is little co-localization of cathepsins B and L (as indicated by yellow-orange staining) and this is seen mostly around the nucleus. PC3 cells plated on Matrigel coverslips (Fig. 2B) demonstrated more cathepsin B staining toward the cell periphery when compared to cells plated on uncoated coverslips (Fig. 2A). Furthermore, there was more cathepsin B positive staining in cell ruffles (Fig. 2B, arrowheads). DU145 also displayed a typical lysosomal/endosomal distribution of cathepsins B and L; however, there were no apparent differences in the localization of cathepsins B in DU145 cells plated on glass compared to cells plated on a thin layer of Matrigel (data not shown).
Cathepsin L immunolocalization did not appear to be affected by the presence of Matrigel; cathepsin L displayed a perinuclear distribution in all groups of cells examined.

Cathepsin $L+B$, cathepsin $B$ and cysteine proteinase inhibitor (CPI) activities. Cathepsin $\mathrm{L}+\mathrm{B}$, cathepsin $\mathrm{B}$, and total CPI activities were measured in extracts and media of PC3 and DU145 cells grown on either uncoated surfaces or surfaces coated with a thin layer of Matrigel. DU145 exhibited higher cathepsin L+B (Fig. 3A and B) and cathepsin B (Fig. 3D and E) activity both in the cell extract and medium compared to PC3 consistent with our previous results (25) and with those of Freidrich et al (3). Cathepsin L+B activity was detected only in media that had been previously incubated with formic acid; the absence of proforms of cathepsin L on Western blots (Fig. 5) suggests that incubation of media at low pH destroys strong cathepsin L-cystatin complexes (34) rather than the presence of pro-forms of cathepsin L. Furthermore, incubation of media with formic acid results in the loss of measurable cathepsin B activity suggesting that cathepsin $\mathrm{B}$ is also secreted in its active form (Fig. 3E).

Matrigel did not significantly affect either cell-associated or secreted cathepsin L+B activity of PC3 and DU145 cells (Fig. 3); however, the percent of total cathepsin L+B activity secreted by PC3 was significantly higher when grown on Matrigel compared to plastic (Fig. 3C).

The distribution of cathepsin B activity between the cell extracts and media was affected by growth on Matrigel in the two cell lines (Fig. 3D-F). A decrease in intracellular activity of cathepsin B and an in increase in secreted cathepsin B was observed in PC3 cells plated on Matrigel compared to cells plated on non-coated controls. In contrast, DU145 cells on Matrigel exhibited increase intracellular B activity but no significant difference in secreted activity (Fig. 3D and E). The 

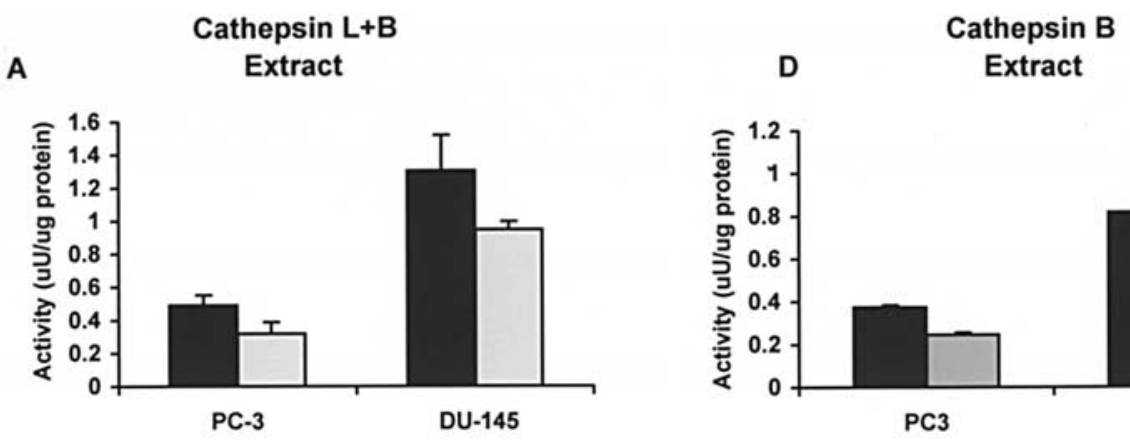

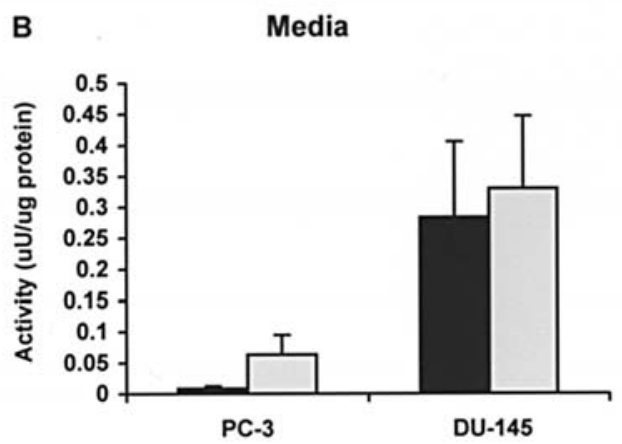

C Percent Cathepsin L+B Activity Secreted

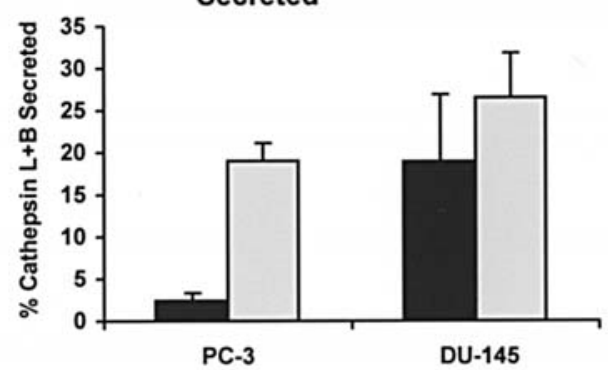

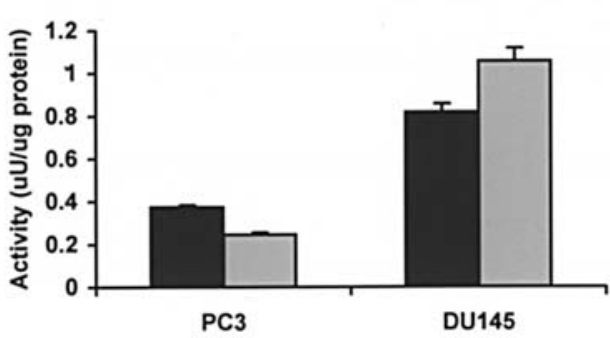

E

Media

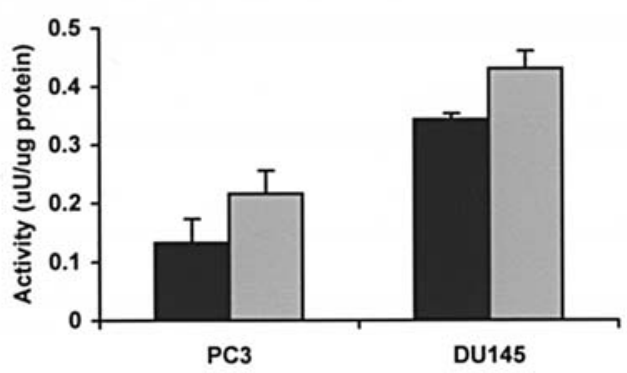

F Percent Cathepsin B Activity Secreted

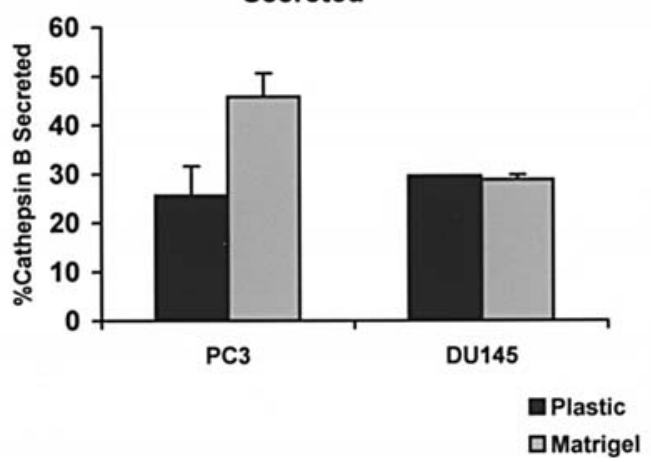

Figure 3. Cathepsin L+B (A-C) and cathepsin B (D-F) activities in cells grown on uncoated (black bars) or Matrigel-coated culture dishes (gray bars). PC3 and DU145 were plated at a concentration of $5.0 \times 10^{5}$ cells per $60-\mathrm{mm}$ dish. The cells were maintained in culture for a total of $48 \mathrm{~h}$ and fed with serum-free media 12-18 h prior to collection. (A) Cell-associated and (B) secreted cathepsin L+B activities were not significantly different in either PC3 or DU145 cells plated on plastic compared to cells plated on Matrigel. (C) The percent of total cathepsin L+B activity found in media was significantly higher in PC3 plated on Matrigel (gray bars) compared to plastic (black bars). (D) Cell-associated and (E) secreted cathepsin B activity. PC3-Matrigel demonstrated a significant increase in secreted cathepsin B activity whereas DU145-Matrigel demonstrated a significant increase in cell-associated activity. (F) The percent of total cathepsin B activity secreted was significantly higher in PC3 when grown on Matrigel (gray bars) compared to plastic (black bars) whereas there was no difference in the percent of secreted cathepsin B activity of DU145 cells.

percent of total cathepsin B secreted confirms an increased secretion by PC3 but not DU145 (Fig. 3F).

Total cysteine proteinase inhibitory (CPI) activity was determined by the ability of cell extracts and media samples to inhibit the cysteine proteinase, papain. PC3 and DU145 had similar amounts of CPI activity in extracts (Fig. 4A) and media (Fig. 4B) as shown previously (25). Matrigel did not significantly affect cell-associated or secreted CPI activity in either cell line (Fig. 4).

Western blot analysis. Western analysis of cathepsins B and L and cystatin $\mathrm{C}$ was performed on cell extracts and media to determine if growth on Matrigel affected the protein levels of the cysteine proteinases and their endogenous CPI, cystatin C. Fig. 5 is a representative of three separate blots performed per protein. Cathepsins $B$ and $\mathrm{L}$ appear as bands corresponding to the $31 \mathrm{kDa}$ active forms of both proteinases. The inactive proforms of cathepsins B or L were not detected in the cell extracts or media. Western analysis indicates an increase in secreted cathepsin B protein in PC3 plated on Matrigel consistent with our activity data (Figs. 5 and $3 \mathrm{~B}$, respectively). An increase in the amount of secreted cathepsin B protein from DU145 grown on Matrigel is also evident in Western blots; however, the increase in secreted cathepsin B activity was not significantly different from cells grown on uncoated surfaces (Figs. 5 and 3E, respectively). 
A CPI Activity in Cell Extract

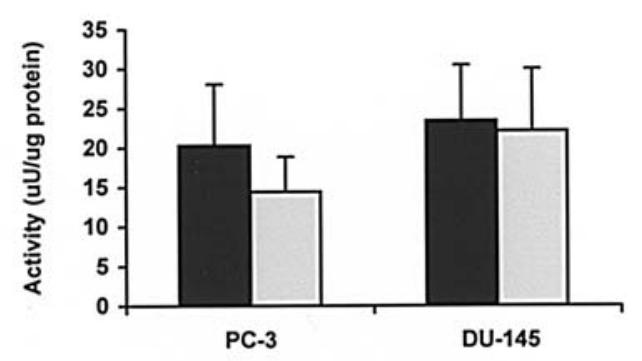

B

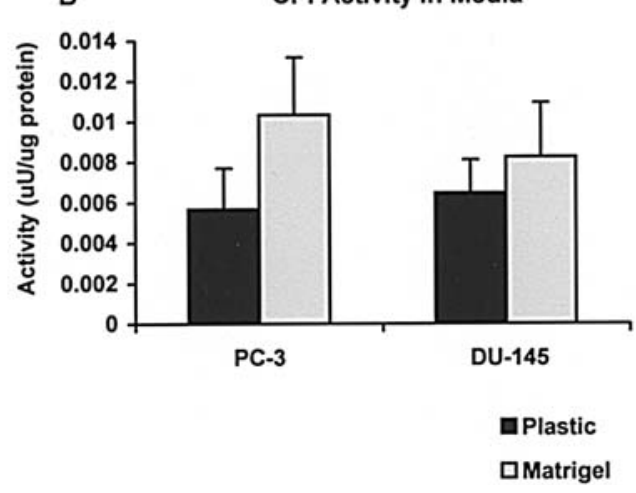

Figure 4. Cysteine proteinase inhibitor (CPI) activity in cells grown on uncoated (black bars) or Matrigel-coated (gray bars) surfaces. The cell extracts and media were boiled for $5 \mathrm{~min}$, centrifuged to remove debris, and incubated with purified papain to measure total CPI activity. CPI activity in the cell extracts (A) or media (B) of both cell lines was not significantly different when comparing cells grown on Matrigel to those grown on plastic.

In agreement with cathepsin L activity data, Matrigel did not induce any changes in cell-associated or secreted cathepsin $\mathrm{L}$ protein in DU145 or PC3 cells.

A $14 \mathrm{kDa}$ band corresponding to the cysteine proteinase inhibitor, cystatin $\mathrm{C}$ was present in the extract and media from both cell lines (Fig. 5); the amounts of cystatin $C$ protein were equivalent in cells grown on plastic compared to those on Matrigel. An additional $25 \mathrm{kDA}$ band was detected in the media of both cell lines; this band may represent cystatin C dimerization $(38,39)$ or different glycoforms of the inhibitor. Various glycoforms of cystatin C similar in size to our $25 \mathrm{kDa}$ band were also detected in media conditioned by hippocampal stem cells (40).

\section{Discussion}

This study demonstrates that the location of the lysosomal proteinase, cathepsin B, is affected by a cell's interaction with basement membrane components. This phenomenon is specific for cathepsin B as cathepsin L is not affected. Furthermore, we found that cathepsins B and L do not co-localize suggesting lysosomal sorting pathways specific for each proteinase. Others also have shown that cathepsins $\mathrm{B}$ and $\mathrm{L}$ do not co-localize to the same vesicle $(16,41)$ suggesting differential localization of cathepsins B and L in some cells.

Cathepsins B, L and other lysosomal cathepsins can be sorted following synthesis of their pro-forms to either lysosomes, regulated secretory lysosomes/vesicles, or constitutory secretory vesicles; evidence for targeting to each of these vesicles has been reported $(42,43)$. Pro-cathepsins B and L are processed to mature forms in the acidic milieu of the lysosome; the mature forms include a single chain of $\sim 30-31 \mathrm{kDa}$ that is further processed to the double chain species of $\sim 25$ and $5 \mathrm{kDa}$. Pro-cathepsin B, its mature forms or both are reportedly secreted from cancer cells depending on cell type and environmental factors. The pro-form of cathepsin B is secreted when normal and tumor breast fibroblasts are plated on collagen I gels (44) whereas collagen I induces the secretion of pro- and mature forms of cathepsin B from invasive melanoma cells (45). An active cathepsin B species of $\sim 31 \mathrm{kDa}$ is secreted pericellularly from a number of human cell lines (46). DU145 cells secrete mature, active forms of cathepsin B following their interaction with either type I collagen or bone fragments (47). In the present study, the secretion of active cathepsin B was up-regulated by Matrigel in PC3 but not in DU145 cells. This discrepancy may be due to the different types of matrices used in the two studies: Matrigel is composed predominantly of type IV collagen whereas bone is composed

\section{Cathepsin L}

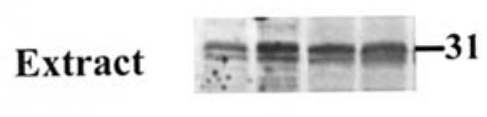

Media

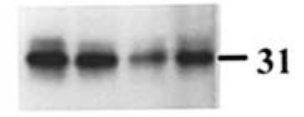

Actin
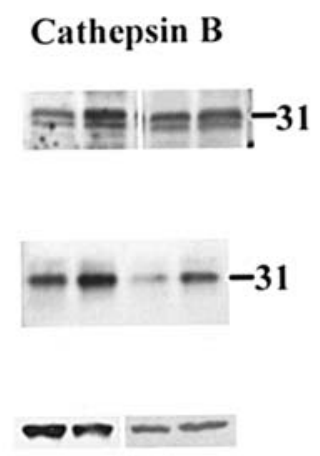

$\begin{array}{llll}1 & 2 & 3 & 4\end{array}$

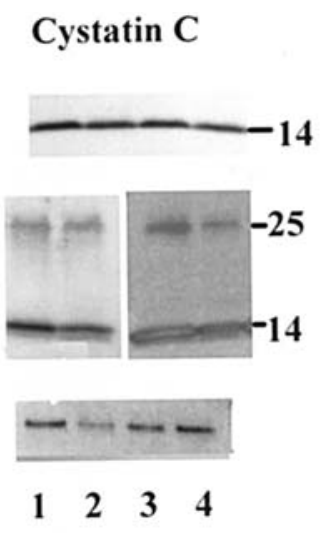

Figure 5. Western blot analysis of cathepsins L and B and cystatin C in cell extracts and conditioned media from PC3 (lanes 1 and 2 ) and DU145 (lanes 3 and 4) grown on uncoated (lanes 1 and 3) or surfaces coated with 70-80 $\mu \mathrm{g}$ Matrigel per $\mathrm{cm}^{2}$ (lanes 2 and 4). Actin is included as the protein loading standard. Both cathepsins L and B appear as the mature single chain $31 \mathrm{kDa}$ form in both extract and media; an increase in cathepsin B density is evident in conditioned media of both PC3 and DU145. The $14 \mathrm{kDa}$ form of cystatin C is present in the extract and media; the media also demonstrates a $25 \mathrm{kDa}$ form of cystatin C immunopositive band. 
of type I collagen. Cell binding to extracellular matrices occurs through surface integrins and specific integrin subunits have been implicated to play a role in cathepsin B secretion $(44,45)$. PC3 expresses different integrin subunits compared to DU145 and these integrin subunits correlate with an increased invasive ability of PC3 (48). The differences in integrin subunit expression between PC 3 and DU145 could also be responsible for the significant increase in secreted cathepsin $\mathrm{B}$ activity by PC3 when grown on Matrigel.

Recent evidence demonstrated that a number of matrixdegrading proteolytic enzymes associate with caveolae (49), which are membrane lipid rafts that function in signal transduction, endocytosis, and lipid transport (50). Caveolae may function as organizing centers for proteolytic events leading to matrix degradation and invasion. Caveolin-1 is a major structural component of caveolae; caveolin-1 may play a crucial role in prostate cancer growth and is secreted by prostate cancer cells $(51,52)$. Cathepsin B localizes to caveolae of colon cancer cells and caveolin-1 is implicated in the secretion of cathepsin B from colorectal carcinoma cells $(8,53)$. It is possible that the selectivity of cathepsin B secretion from PC3 cells and not cathepsin L is due to the association of cathepsin B with caveolin-1. Although there is strong evidence that caveolin-1 functions as a tumor promoter in prostate cancer, its role in modulating cathepsin B secretion in prostate cancer cells is not known and needs to be assessed.

In this study, cells plated on uncoated surfaces or on a thin layer of Matrigel exhibited similar morphologies, but differed remarkably from cells plated on a gel-like matrix. PC3 and DU145 formed typical monolayers on uncoated surfaces and thin Matrigel layers; whereas on gels, the cells clumped together and formed web-like structures connecting aggregates of cells. Similar patterns of cell organization were seen in human airway smooth muscle (54), primary rat mammary (55), PC3 (22), and DU145 cells (56) when cultured on Matrigel gels. The difference between a thin layer of Matrigel versus a thin gel is that a thin layer of Matrigel is more rigid than a gel because of its closer association with the underlying glass/plastic surface. The physical properties of a matrix in addition to its constituents influence morphology; mechanical forces transmitted across the cell surface due to matrix flexibility modulate specific cell signaling pathways induced by the binding of matrix components to cell surface receptors such as the integrins $(55,57)$. We conclude from our results that the web-like structures and cell aggregates formed on Matrigel gels are due to the more flexible properties of the gel surface compared to a Matrigel thin layer. We continued our studies on cathepsin activity using surfaces covered with a thin layer of Matrigel to minimize the influence of cell shape change on extracellular-matrix-mediated signaling. Changes in cell shape accompany changes in cytoskeleton organization; the latter promotes vesicular transport and fusion with the plasma membrane as has been shown (58-60). Although the effects of extracellular matrix components on lysosomal cathepsin activity and localization has been described in this study and by others, future studies that include the effects of morphology on lysosomal proteinase localization and secretion are needed. Understanding the dynamics of lysosomes and lysosomal cysteine proteinase secretion during cancer cell invasion is essential to the goal of eradicating cancer and its metastasis.

\section{Acknowledgements}

This study was supported by a grant from the Elsa U. Pardee Foundation and an Intramural Research Incentive Grant from the University of Louisville School of Medicine. We thank Dr Fred J. Roisen, Dr Chengliang Lu and George Harding for their assistance with the microscopic images.

\section{References}

1. Demers M, Couillard J, Belanger and St. Pierre Y: New roles for matrix metalloproteinases in metastasis. Crit Rev Immunol 25: 493-523, 2005.

2. Bellezza T, Aisa MC, Palazzo R, Costanzi E, Mearini E and Minelli A: Extracellular matrix degrading enzymes at the prostasome surface. Prostate Cancer Prostatic Dis 8: 344-348, 2005.

3. Friedrich B, Jung K, Lein M, Turk I, Rudolph B, Hampel G, Schnorr D and Loening SA: Cathepsins B, H, L and cysteine proteinase inhibitors in malignant prostate cell lines, primary cultured prostatic cells and prostatic tissue. Eur J Cancer 35: 138-144, 1999.

4. Fernandez PL, Farre X, Nadal A, Fernandez E, Peiro N, Sloane BF, Shi G-P, Chapman HA, Campo E and Cardesa A: Expression of cathepsins $\mathrm{B}$ and $\mathrm{S}$ in the progression of prostate carcinoma. Int J Cancer 95: 51-55, 2001.

5. Sloane BF and Moin K: Pericellular cathepsin B and malignant progression. Cancer Metastasis Rev 22: 271-286, 2003.

6. Ravanko K, Jarvinen K, Helin J, Kalkkinen N and Holtta E: Cysteine cathepsins are central contributors of invasion of cultured adenosylmethionine decarboxylase-transformed rodent fibroblasts. Cancer Res 64: 8831-8838, 2004.

7. Tao K, Li J, Warner J, MacLeod K, Miller FR and Sahagian GG: Multiple lysosomal trafficking phenotypes in metastatic mouse mammary tumor cell lines. Int J Oncol 19: 1333-1339, 2001.

8. Cavallo-Medved D, Mai J, Dosescu J, Sameni M and Sloane BF: Caveolin-1 mediates the expression and localization of cathepsin $\mathrm{B}$, pro-urokinase plasminogen activator and their cell-surface receptors in human colorectal carcinoma cells. J Cell Sci 118: 1493-1503, 2005.

9. Buck MR, Karustis DG, Day NA, Honn KV and Sloane BF: Degradation of extracellular matrix protein by human cathepsin B from normal and tumor tissues. Biochem J 282: 273-278, 1992.

10. Ishidoh $\mathrm{K}$ and Kominami E: Procathepsin L degrades extracellular matrix protein in the presence of glycosaminoglycans in vitro. Biochem Biophys Res Commun 217: 624-631, 1995.

11. Mason RW, Johnson DA, Barrett AJ and Chapman HA: Elastinolytic activity of human cathepsin L. Biochem J 233: 925-927, 1986.

12. Maciewicz RA, Etherington DJ, Kos J and Turk V: Collagenolytic cathepsins of rabbit spleen: a kinetic analysis of collagen degradation and inhibition by chicken cystatin. Collagen Relat Res 7: 295-304, 1987.

13. Lah TT, Buck MR, Honn KV, Crissman JD, Rao NC, Liotta AL and Sloane BF: Degradation of laminin by tumor cathepsin B. Clin Exp Metastasis 7: 461-469, 1989.

14. Guinec N, Dalet-Fumeron V and Pagano M: 'In vitro' study of basement membrane degradation by the cysteine proteinases, cathepsins B, B-like, and L. Biol Chem Hoppe-Seyler 374: 1135-1146, 1993

15. Murphy G, Ward R, Gavrilovic J and Atkinson S: Physiological mechanisms for metalloproteinase activation. Matrix 1 (Suppl 1): 224-230, 1992.

16. Guo M, Mathieu PA, Linebaugh B, Sloane BF and Reiners JJ: Phorbol ester activation of a proteolytic cascade capable of activating latent transforming growth factor-3. J Biol Chem 277: 14829-14837, 2002.

17. Ahram M, Sameni M, Qiu R-G, Linebaugh B, Kirn D and Sloane BF: Rac1-induced endocytosis is associated with intracellular proteolysis during migration through a three-dimensional matrix. Exp Cell Res 260: 292-303, 2000.

18. Sameni M, Moin K and Sloane BF: Imaging proteolysis by living human breast cancer cells. Neoplasia 2: 496-504, 2000.

19. Boudreau N and Bissell MJ: Extracellular matrix signaling: integration of form and function in normal and malignant cells. Curr Opin Cell Biol 10: 640-646, 1998. 
20. Martin KH, Slack JK, Boerner SA, Martin CC and Parsons JT: Integrin connections map: to infinity and beyond. Science 296 : 1652-1653, 2002.

21. Bissell MJ, Radisky DC, Rizki A, Weaver VM and Petersen OW: The organizing principle: microenvironmental influences in the normal and malignant breast. Differentiation 70: 537-546, 2002.

22. Lang SH, Sharrard RM, Stark M, Villette JM and Maitland NJ: Prostate epithelial cell lines form spheroids with evidence of glandular differentiation in three dimensional Matrigel cultures. Br J Cancer 85: 590-599, 2001.

23. Pretlow TG, Delmoro CM, Dilley GG, Spadafora CG and Pretlow TP: Transplantation of human prostatic carcinoma into nude mice in matrigel. Cancer Res 51: 3814-3817, 1991.

24. Passaniti A, Isaacs JT, Haney JA, Adler SW, Cujdik TJ and Long PV: Stimulation of human prostatic carcinoma tumor growth in athymic mice and control of migration in culture by extracellular matrix. Int J Cancer 51: 318-324, 1992.

25. Colella R, Goodwyn E and Gopal P: Increased cell density decreases cysteine proteinase inhibitor activity and increases invasive ability of two prostate tumor cell lines. Cancer Lett 185: 163-172, 2002.

26. Sinha AA, Gleason DF, Deleon OF, Wilson MJ and Sloane BF: Localization of a biotinylated cathepsin B oligonucleotide probe in human prostate including invasive cells and invasive edges by in situ hybridization. Anat Rec 235: 233-240, 1993.

27. Sinha AA, Quast BJ, Wilson MJ, Reddy PK, Gleason DF and Sloane BF: Codistribution of procathepsin B and mature cathepsin $\mathrm{B}$ forms in human prostate tumors detected by confocal and immunofluorescence microscopy. Anat Rec 252: 281-289, 1998.

28. Sinha AA, Quast BJ, Korkowski JC, Wilson MJ, Reddy PK, Ewing SL, Sloane BF and Gleason DF: The relationship of cathepsin B and stefin A mRNA localization identifies a potentially aggressive variant of human prostate cancer within a Gleason histologic score. Anticancer Res 19: 2821-2829, 1999.

29. Sinha AA, Quast BJ, Wilson MJ, Fernandes ET, Reddy PK, Ewing SL and Gleason DF: Prediction of pelvic lymph node metastasis by the ratio of cathepsin B to stefin A in patients with prostate carcinoma. Cancer 94: 3141-3149, 2002.

30. Mickey DD, Stone KR, Wunderli H, Mickey G and Paulson DF: Characterization of a human prostate adenocarcinoma cell line (DU145) as a monolayer culture and a solid tumor in athymic mice. In: Models for Prostate Cancer, Murphy GP (ed). Prog Clin Biol Res 37: 67-84, 1980.

31. Kaign ME, Narayan KS, Ohnuki Y, Lechner JF and Jones LW: Establishment and characterization of a human prostatic carcinoma cell line (PC3). Investig Urol (Berl) 17: 16-23, 1979.

32. Barrett AJ and Kirsche H: Cathepsin B, cathepsin H, and cathepsin L. Methods Enzymol 80: 535-561, 1981

33. Lowry OH, Rosbrough NJ, Farr AL and Randall RJ: Protein measurement with the folin phenol reagent. J Biol Chem 193: 265-275, 1951 .

34. Mason RW, Green GDJ and Barrett AJ: Human liver cathepsin L. Biochem J 226: 233-241, 1985.

35. Troen BR, Ascherman D, Atlas D and Gottesman MM: Cloning and expression of the gene for the major excreted protein of transformed mouse fibroblasts. J Biol Chem 263: 254-261, 1988.

36. Mach L, Mort JS and Glossl J: Maturation of human procathepsin B. J Biol Chem 269: 13030-13035, 1994

37. Li SC, Chen GF, Chan PSF, Choi HL, Ho S-M and Chan FL: Altered expression of extracellular matrix and proteinases in Noble rat prostate gland after long-term treatment with sex steroids. Prostate 49: 58-71, 2001.

38. Grubb AO: Cystatin C - properties and use as diagnostic marker. Adv Clin Chem 35: 63-99, 2000.

39. Stachowiak K, Rodziewwicz-Motowidlo S, Sosnowska R, Kasprzykowski F, Lankiewicz L, Grugg A and Grzonka Z: Effect of antisense peptide binding on the dimerization of human cystatin C - gel electrophoresis and molecular modeling studies. Acta Biochim Pol 51: 153-160, 2004

40. Dahl A, Eriksson PS, Davidsson P, Persson AI, Ekman R and Westman-Brinkmalm A: Demonstration of multiple novel glycoforms of the stem cell survival factor CCg. J Neurosci Res 77: 9-14, 2004

41. Ulbricht B, Henny H, Horstmann H, Spring H, Faigle W and Spiess E: Influence of 12(S)-hydroxyeicosatetraenoic acid (12(S)-HETE) on the location of cathepsin B and cathepsin L in human lung tumor cells. Eur J Cell Biol 74: 294-301, 1997.
42. Andrews NW: Regulated secretion of conventional lysosomes. Trends Cell Biol 10: 316-321, 2000.

43. Nishimura Y, Sameni M and Sloane BF: Malignant transformation alters intracellular trafficking of lysosomal cathepsin D in human breast epithelial cells. Pathol Oncol Res 4: 283-296, 1998.

44. Koblinski JE, Dosescu J, Sameni M, Moin K, Clark K and Sloane BF: Interaction of human breast fibroblasts with collagen I increases secretion of procathepsin B. J Biol Chem 277: 32220-32227, 2002

45. Klose A, Wilbrand-Hennes A, Zigrino P, Weber E, Krieg T, Mauch $\mathrm{C}$ and Hunzelmann N: Contact of high-invasive, but not low-invasive, melanoma cells to native collagen I induces the release of mature cathepsin B. Int J Cancer 118: 2735-2743, 2006.

46. Linebaugh BE, Sameni M, Day NA, Sloane BF and Keppler D: Exocytosis of active cathepsin B. Eur J Biochem 264: 100-109, 1999.

47. Podgorski I, Linebaugh BE, Sameni M, Jedeszko C, Sunita B, Cher ML and Sloane BF: Bone microenvironment modulates expression and activity of cathepsin B in prostate cancer. Neoplasia 7: 207-223, 2005.

48. Witkowski CM, Rabinovitz I, Nagle R, Affinito K-SD and Cress AE: Characterization of integrin subunits, cellular adhesion and tumorigenicity of four human prostate cell lines. J Cancer Res Clin Oncol 119: 637-644, 1993.

49. Sloane BF, Yan S, Podgorski I, Linebaugh BE, Cher ML, Mai J, Cavallo-Medved D, Sameni M, Dosescu J and Moin K: Cathepsin $\mathrm{B}$ and tumor proteolysis: Contribution of the tumor microenvironment. Semin Cancer Biol 15: 149-157, 2005.

50. Van Deurs B, Roepstorff K, Hommelgaard AM and Sandvig K: Caveolae: anchored, multifunctional platforms in the lipid ocean. Trends Cell Biol 13: 92-100, 2003.

51. Tahir SA, Yang G, Ebara S, Timme TL, Satoh T, Li L, Goltsov A, Ittmann M, Morrisett JD and Thompson TC: Secreted caveolin-1 stimulates cell survival/clonal growth and contributes to metastasis in androgen-insensitive prostate cancer. Cancer Res 61: 3882-3885, 2001.

52. Mouraviev V, Li L, Tahir SA, Yang G, Timme TM, Goltsov A, Ren C, Satoh T, Wheeler TM, Ittmann MM, Miles BJ, Amato RJ, Kadmon D and Thompson TC: The role of caveolin-1 in androgen insensitive prostate cancer. J Urology 168: 1589-1596, 2002.

53. Cavallo-Medved D, Dosescu J, Linebaugh BE, Sameni M, Rudy D and Sloane BF: Mutant K-ras regulates cathepsin B localization in caveolae of human colorectal carcinoma cells. Neoplasia 5: 1-13, 2003.

54. Hirst SJ, Twort CHC and Lee TH: Differential effects of extracellular matrix proteins on human airway smooth muscle cell proliferation and phenotype. Am J Respir Cell Mol Biol 23: 335-344, 2000.

55. Larsen MC, Brake PB, Pollenz RS and Jefcoate CR: Linked expression of Ah receptor, ARNT, CYP1A1, and CYP1B1 in rat mammary epithelia, in vitro, is each substantially elevated by specific extracellular matrix interactions that precede branching morphogenesis. Toxicol Sci 82: 46-61, 2004.

56. Webber MM, Bello D, Klunman HK and Hoffman MP: Acinar differentiation by non-malignant immortalized human prostatic epithelial cells and its loss by malignant cells. Carcinogenesis 18: 1225-1231, 1997.

57. Ingber DE: Cancer as a disease of epithelial-mesenchymal interactions and extracellular matrix regulation. Differentiation 70: 547-560, 2002.

58. Nishimura Y, Yoshioka K, Bernard O, Himeno M and Itoh K: LIM kinase 1: evidence for a role in the regulation of intracellular vesicle trafficking of lysosomes and endosomes in human breast cancer cells. Eur J Cell Biol 83: 369-380, 2004.

59. Sahai E and Marshall CJ: Differing modes of tumor cell invasion have distinct requirements for rho/ROCK signaling and extracellular proteolysis. Nature Cell Biol 5: 711-719, 2003.

60. Buth H, Wolters B, Hartwig B, Meier-Bornheim R, Veith H, Hansen M, Sommerhoff CP, Schaschke N, Machleidt W, Fusenig NE, Boukamp P and Brix K: HaCaT keratinocytes secrete lysosomal cysteine proteinases during migration. Eur $\mathbf{J}$ Cell Biol 83: 781-795, 2004. 